\title{
Water for Long Island: Now and for the Future
}

\section{Do You Ever Wonder Where Your Water Comes From?}

If you live in Nassau or Suffolk County, the answer is, groundwater. Groundwater is water that started out as precipitation (rain and snow melt) and seeped into the ground. This seepage recharges the freshwater stored underground, in the spaces between the grains of sand and gravel in what are referred to as aquifers. Long Island has three primary aquifers - the upper glacial, Magothy, and Lloyd — which are part of the Long Island aquifer system. Currently [2019], this aquifer system contains about 50 trillion gallons of freshwater. groundwater, which flows seaward toward the coast, meets the salty groundwater, which flows landward toward the shore, is referred to as the freshwater/saltwater interface. If too much fresh groundwater is pumped from an aquifer near this interface, salty groundwater will move inland, affecting the water quality in wells near the interface. If a pumping well pulls in salty groundwater (by a process referred to as saltwater intrusion), that water is no longer safe to drink. Once intruded, an aquifer no longer can provide drinking water until the saltwater is flushed out naturally by freshwater, which can take decades to as much as centuries.

\section{Why Is Groundwater Important?}

Groundwater pumped from these aquifers provides essentially all the drinking water for the nearly 3 million people that live on Long Island; the U.S. Environmental Protection Agency (EPA) has designated them as a sole-source aquifer system. About 425 million gallons of water is pumped daily from tens to hundreds of feet below the ground by more than 1,500 publicsupply wells throughout the island. The good news is that all this pumping only removes a small amount of the total groundwater beneath the island and precipitation replenishes the aquifer system at a rate of nearly four times the amount that is pumped. This replenishment also sustains the island's groundwater-fed ponds, streams, wetlands, and coastal waters. The bad news is that not all this groundwater is available, or safe, to drink.

\section{Why Is Saltwater Intrusion a Concern?}

Because Long Island is surrounded by saltwater at the surface and at varying depths below ground, the freshwater that replenishes the aquifer system and slowly flows through it and that eventually exits the aquifer system at the coast is what keeps the saltwater in the sediments that are offshore from pushing landward beneath Long Island. The area where the fresh

Block diagram showing groundwater flow on Long Island, New York.

\section{What Are Other Groundwater Quantity and Quality Concerns?}

Another issue with pumping groundwater from a coastal aquifer system is that it can reduce the amount of freshwater that flows toward the shoreline. This freshwater naturally discharges into the coastal bays and estuaries and is needed to maintain the proper salinity in coastal waters to support the shellfish and finfish in these marine habitats.

Removing groundwater from the aquifer system also affects surface waters away from the coast. Overpumping can lower the water table (the level below the ground in which sediments are saturated with water); if the water table is lowered below the bottoms of ponds, streams, and wetlands, then no groundwater can sustain them, and they will dry up.

Quantity is not the only water-related issue facing Long Island. Essentially all the groundwater in the aquifers originated as precipitation at land surface so any contaminant releases or spills at land surface can potentially affect the quality of the underlying groundwater. Examples of possible contamination sources include fertilizers and pesticides, domestic wastewater 
from cesspools, and chemical spills from small businesses (such as dry cleaners and gas stations) or large industries and military installations. All these factors may threaten the quality of the groundwater that is pumped for drinking water.

\section{How Is the U.S. Geological Survey Assessing Groundwater Sustainability?}

The balancing act of meeting the demand for drinking water without harming the environment is referred to as aquifer sustainability and it is of vital importance to the residents of Long Island as well as water-resource managers and the Federal, State, and local regulators tasked with protecting these valuable resources. In response to concerns about maintaining aquifer sustainability, the U.S. Geological Survey (USGS) has partnered with the New York State Department of Environmental Conservation (NYSDEC) to conduct a comprehensive study of the Long Island aquifer system. This study is providing the information needed to assess water quantity, saltwater intrusion, and effects on ponds, streams, wetlands, and coastal waters from reduced groundwater outflow and to help manage aquifer sustainability. This USGS groundwater sustainability study has four major parts: (1) updating hydrogeologic (aquifer sediment) maps, (2) determining the present day [2019] location of the freshwater/saltwater interface, (3) constructing a groundwater-flow model, and (4) using the model to predict the most likely outcomes of potential management decisions and changes in environmental conditions.

Updated hydrogeologic maps are being created by combining existing knowledge with new information collected as part of this study: the USGS has been studying the area's hydrogeology for more than a century. Even though our scientific knowledge of the Long Island aquifer system has increased, there still remain some gaps in our understanding of the complex hydrogeology of this aquifer system. To help fill in these gaps, the USGS is drilling up to 25 new monitoring wells hundreds of feet deep into the

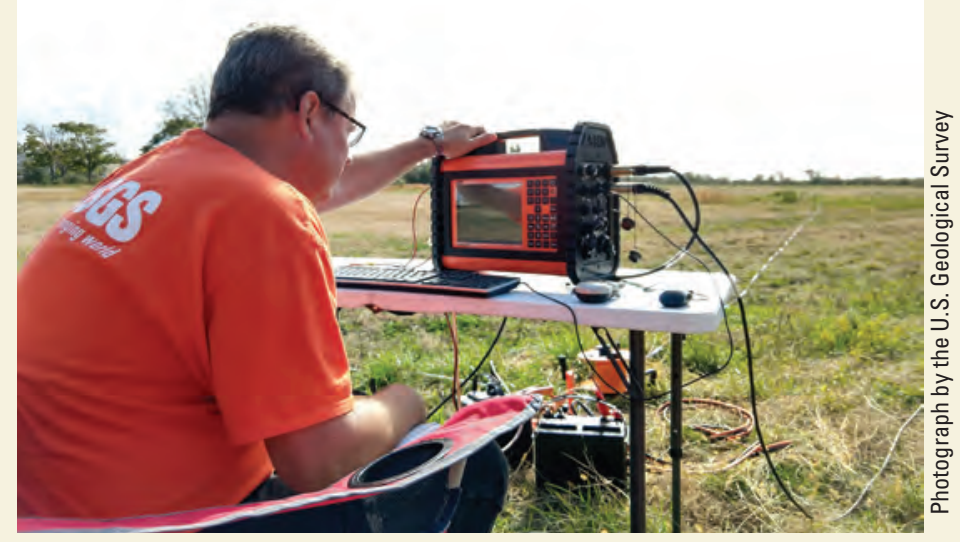

U.S. Geological Survey scientist using surface geophysical equipment to measure electrical conductivity of the subsurface. subsurface to measure water levels in the deep aquifers and to obtain samples of the sediments that make up these aquifers. Characterizations of these sediments can then be used by hydrogeologists to improve existing maps of aquifer sediment type, depth, and thickness.

The study seeks to determine the location of the freshwater/saltwater interface, where present, by measuring how easily the water in these new wells conducts electricity. The saltier the water is, the easier it conducts more electricity. Where drilling a new well is impractical, the conductivity of groundwater can be estimated above ground using surface geophysical techniques. Electrical conductivity measured in wells and from land surface can then be used by geophysicists to map the location of the freshwater/saltwater interface.

A groundwater-flow model is a computer model that mathematically calculates how groundwater flows through an aquifer system. The hydrogeologic information from previous investigations will be combined with the information obtained from the new wells and inputted into a three-dimensional groundwater flow model to reproduce (or simulate) current [2019] hydrologic conditions (water levels and flows) and used to predict the most likely outcomes from changes in pumping and sewering and potential changes in the environment, such as sea-level rise and prolonged droughts.

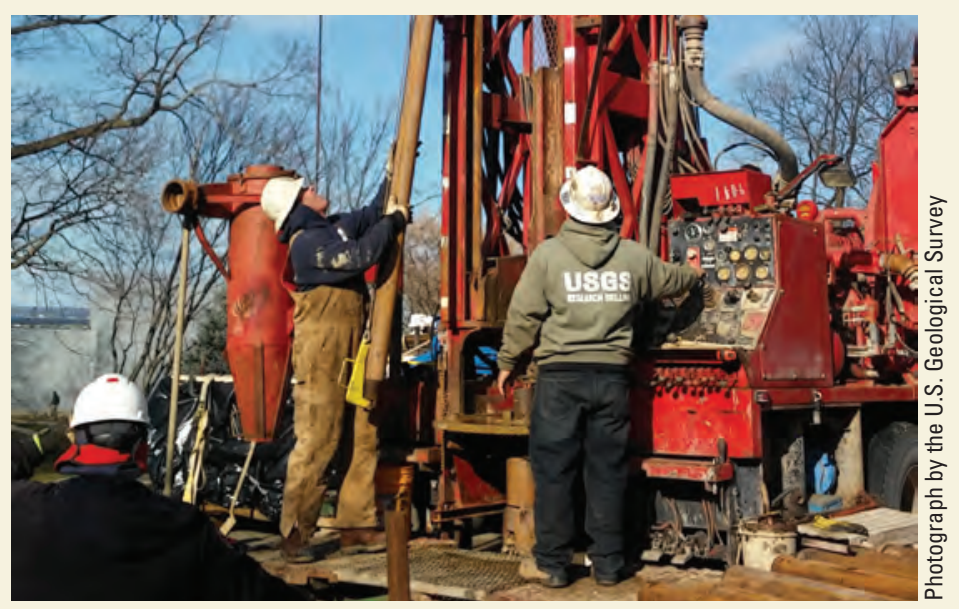

U.S. Geological Survey staff drilling a monitoring well on Long Island, New York.

By John Masterson and Robert Breault

For more information, contact

Director, New York Water Science Center

U.S. Geological Survey

dc_ny@usgs.gov

https://ny.water.usgs.gov

https://usgs.gov/LonglslandGroundwater

Layout design by Susan Meacham,

Pembroke Publishing Service Center

ISSN 2327-6916 (print) ISSN 2327-6932 (online) https://doi.org/10.3133/fs20193052 